\title{
Differential response to sulfur nutrition of two common bean genotypes differing in storage protein composition
}

\section{Sudhakar Pandurangan ${ }^{1,2}$, Mark Sandercock ${ }^{3}$, Ronald Beyaert ${ }^{2}$, Kenneth L. Conn ${ }^{2}$, Anfu Hou ${ }^{3}$ and Frédéric Marsolais ${ }^{1,2} *$}

\author{
1 Department of Biology, University of Western Ontario, London, ON, Canada \\ ${ }^{2}$ Genomics and Biotechnology, Southern Crop Protection and Food Research Centre, Agriculture and Agri-Food Canada, London, ON, Canada \\ ${ }^{3}$ Cereal Research Centre Morden, Agriculture and Agri-Food Canada, Morden, MB, Canada
}

Edited by:

Stanislav Kopriva, University of Cologne, Germany

Reviewed by:

Rachel Amir, Migal - Tel Hai, Israel Christian Zörb, University of Hohenheim, Germany

*Correspondence:

Frédéric Marsolais, Genomics and Biotechnology, Southern Crop

Protection and Food Research Centre, Agriculture and Agri-Food Canada, 1391 Sandford Street, London, Ontario, N5V 4T3, Canada e-mail: frederic.marsolais@agr.gc.ca
It has been hypothesized that the relatively low concentration of sulfur amino acids in legume seeds might be an ecological adaptation to nutrient poor, marginal soils. SARC1 and SMARC1N-PN1 are genetically related lines of common bean (dry bean, Phaseolus vulgaris) differing in seed storage protein composition. In SMARC1N-PN1, the lack of phaseolin and major lectins is compensated by increased levels of sulfur-rich proteins, resulting in an enhanced concentration of cysteine and methionine, mostly at the expense of the abundant non-protein amino acid, $S$-methylcysteine. To identify potential effects associated with an increased concentration of sulfur amino acids in the protein pool, the response of the two genotypes to low and high sulfur nutrition was evaluated under controlled conditions. Seed yield was increased by the high sulfate treatment in SMARC1N-PN1. The seed concentrations of sulfur, sulfate, and $S$-methylcysteine were altered by the sulfur treatment in both genotypes. The concentration of total cysteine and extractible globulins was increased specifically in SMARC1N-PN1. Proteomic analysis identified arcelin-like protein 4, lipoxygenase-3, albumin-2, and alpha amylase inhibitor beta chain as having increased levels under high sulfur conditions. Lipoxygenase-3 accumulation was sensitive to sulfur nutrition only in SMARC1N-PN1. Under field conditions, both SARC1 and SMARC1N-PN1 exhibited a slight increase in yield in response to sulfur treatment, typical for common bean.

Keywords: sulfur nutrition, seed yield, sulfur amino acids, globulin, lipoxygenase, albumin, lectin, common bean

\section{INTRODUCTION}

Common bean (dry bean, Phaseolus vulgaris) is an important source of protein and fiber in human diets. Like other grain legumes, its protein quality is sub-optimal, being limited by the levels of the essential sulfur amino acids, methionine, and cysteine. During the past decades, a lot of effort has been dedicated to improving protein quality in grain legumes, primarily using transgenic approaches (Krishnan, 2005; Ufaz and Galili, 2008; Amir et al., 2012; Galili and Amir, 2013). Transgenic expression of foreign proteins can be limited by the supply of sulfur, and often results in a shift of sulfur away from endogenous, sulfur-rich proteins (Streit et al., 2001; Tabe and Droux, 2002; Chiaiese et al., 2004). Table 1 lists the different experiments that were performed involving transgenic expression of sulfur-rich proteins in legumes and their outcomes. In Vicia narbonensis, co-expression of Brazil nut $2 \mathrm{~S}$ albumin and a feedback-insensitive, bacterial aspartate kinase was associated with increased sulfur concentration in seed (Demidov et al., 2003). A common concern with these approaches is the potential allergenicity of the foreign proteins (Nordlee et al., 1996; Kelly and Hefle, 2000; Krishnan et al., 2010). A possible solution to this problem is the expression of a de novo synthetic protein, MB-16. An alternative approach involves the transgenic manipulation of sulfur amino acid pathways. Overexpression of cytosolic serine acetyltransferase in developing soybean seed led to a 70\% increase in total cysteine concentration (Kim et al., 2012). Expression of a feedback-insensitive Arabidopsis cystathionine $\gamma$ synthase (AtD-CGS), encoding a protein lacking 30 amino acids in the N-terminal domain, raised total methionine concentration by 1.8 to 2.3 -fold, with an overall increase in seed protein concentration (Song et al., 2013). By contrast, expression of the feedback-insensitive mto1-1 allele, harboring a point mutation, led to elevated levels of free methionine, but not total methionine in soybean, whereas in azuki bean, the levels of cystathionine were raised while total methionine concentration was actually decreased (Hanafy et al., 2013a,b). A completely different approach proposed to improve protein quality in common bean involves the introduction of highly digestible phaseolin types from wild accessions by conventional breeding (Montoya et al., 2010). Based on in vitro protein digestibility corrected amino acid score, genotypes having highly digestible phaseolin types could increase bioavailable sulfur amino acids by approximately $30 \%$ as compared with S type phaseolin present in Mesoamerican cultivars.

Grain yield in legumes has a low heritability due to environmental variables. Consequently, agronomic practices combined with proper fertilizer management heavily influence yield. Sulfur, which has long been known to play a major role in plant metabolism (Takahashi et al., 2011), increases yield in common bean (Malavolta et al., 1987) and influences seed quality via the 
Table 1 | Attempts to improve sulfur amino acid concentration in legumes by transgenic expression of sulfur-rich proteins.

\begin{tabular}{|c|c|c|c|}
\hline Crop plant & Foreign protein & Increase in sulfur amino acids & Reference \\
\hline Soybean & Brazil nut 2S albumin & Methionine $26 \%$ & Townsend and Thomas (1994) \\
\hline Soybean & 15 kDa $\delta$-zein & Methionine by $20 \%$ and cysteine by $35 \%$ & Dinkins et al. (2001) \\
\hline Soybean & 27 kDa $\gamma$-zein & Methionine by $19 \%$ and cysteine by $30 \%$ & Li et al. (2005) \\
\hline Soybean & 11 kDa $\delta$-zein & Methionine (alcohol soluble fraction) & Kim and Krishnan (2004) \\
\hline Common bean & Brazil nut 2S albumin & Methionine by $20 \%$ & Aragão et al. (1999) \\
\hline Lupin & Sunflower seed albumin & Methionine by $90 \%$ & Molvig etal. (1997), Tabe and Droux (2002) \\
\hline Chickpea & Sunflower seed albumin & Methionine by $90 \%$ & Chiaiese et al. (2004) \\
\hline Vicia narbonensis & $\begin{array}{l}\text { Brazil nut } 2 S \text { albumin and feedback- } \\
\text { insensitive aspartate kinase }\end{array}$ & Methionine by $100 \%$ and cysteine by $20 \%$ & Demidov et al. (2003) \\
\hline Soybean & MB-16 & Methionine by $16 \%$ and cysteine by $66 \%$ & Zhang etal. (2014) \\
\hline
\end{tabular}

proportion of sulfur containing amino acids, cysteine, and methionine. Sulfate is the most significant and readily mobilized form of sulfur. Sulfate taken up by the roots is reduced to sulfide and further incorporated into cysteine. Cysteine is converted to methionine or incorporated into glutathione and proteins. Sulfate, and/or organic forms of sulfur, such as glutathione (Anderson and Fitzgerald, 2001) or S-methylmethionine (Bourgis et al., 1999; Lee et al., 2008; Tan et al., 2010), is transported through the phloem, followed by uptake by transporters into the developing embryo and translocation between seed tissues (Zuber et al., 2010). Delivery of adequate sulfur to seed tissues is needed for maximizing production and to improve protein quality (Hawkesford and De Kok, 2006). Nutrient status of the plant regulates the uptake and assimilation of sulfate (Smith et al., 1995; Buchner et al., 2004). Studies have shown that a decrease in sulfate availability results in a several-fold enhanced expression of sulfate transporter genes, which enhances the capacity for sulfate uptake (Hawkesford, 2000, 2003). Sulfur fertilization favorably affects protein quality by increasing the expression of proteins rich in sulfur amino acids. Control of seed protein accumulation by the sulfur status has been well documented in several legumes, including globulins in soybean and lupine (Blagrove et al., 1976; Gayler and Sykes, 1985), and globulins, and albumins in pea (Chandler et al., 1983, 1984; Higgins et al., 1987). Reduced expression of pea legumin and albumin 1 genes in response to sulfur deficiency was further confirmed in transgenic tobacco (Rerie et al., 1991; Morton et al., 1998). In general, high sulfur stimulates the expression of sulfurrich globulins and albumins while sulfur deficiency increases the expression of sulfur-poor globulins. In soybean, the accumulation of the sulfur-poor $\beta$-subunit of $\beta$-conglycinin is repressed by exogenous methionine (Holowach et al., 1984, 1986). This was confirmed in transgenic Arabidopsis (Naito et al., 1995). The immediate metabolic precursor of cysteine, $O$-acetylserine, seems involved in the up-regulation of the $\beta$-subunit of $\beta$-conglycinin under conditions of sulfur deficiency (Kim et al., 1999). A high nitrogen to sulfur ratio not only increases the accumulation of the $\beta$-subunit of $\beta$-conglycinin, but also reduces the levels of sulfur-rich Bowman-Birk inhibitor (Krishnan et al., 2005). Recent research has focused on adaptation of legumes to sulfur deficiency, highlighting the possible role of a vacuolar sulfate transporter in Medicago truncatula (Zuber et al., 2013). This research is relevant to improvement of sulfur use efficiency (De Kok et al., 2011).

Crop plants mitigate the effect of silencing or deficiency in storage proteins through rebalancing of the seed proteome (Marsolais et al., 2010; Herman, 2014; Wu and Messing, 2014). SARC1 and SMARC1N-PN1 are related genotypes of common bean differing in seed protein composition (Osborn et al., 2003). They share 87.5 and $83.6 \%$ of the recurrent, Sanilac parental background, respectively. SARC1 integrates the lectin arcelin-1 from a wild accession. SMARC1N-PN1 lacks phaseolin and major lectins, through introgressions from a $P$. coccineus accession and Great Northern 1140, respectively. These changes are associated with an increased concentration of methionine and cysteine, by 10 and $70 \%$, respectively, concomitant with $70 \%$ decrease in $S$ methylcysteine concentration (Taylor et al., 2008). Proteomic and transcript profiling indicated that several sulfur-rich proteins have increased levels in SMARC1N-PN1, including the $11 \mathrm{~S}$ globulin legumin, albumin-2, defensin D1, Bowman-Birk type proteinase inhibitor 2, albumin-1, basic 7S globulin, and Kunitz trypsin protease inhibitor (Marsolais et al., 2010; Yin et al., 2011; Liao et al., 2012). SARC1 and SMARC1N-PN1 offer a unique system to investigate how related legume genotypes, harboring natural genetic variation in storage protein composition, respond to sulfur deficiency. The presence of an endogenous sink for sulfur in SMARC1N-PN1 is associated with an increased plasticity of the seed composition in response to sulfur nutrition.

\section{MATERIALS AND METHODS PLANT MATERIALS AND GROWTH CONDITIONS}

SARC1 and SMARC1N-PN1 were evaluated for their response to sulfur nutrition by fertilizing with a nutrient solution containing low sulfur (LS) or high sulfur (HS) as described in previous work with common bean (Sánchez et al., 2002) and chickpea (Chiaiese et al., 2004), with modifications (Pandurangan et al., submitted to Sulfur Metabolism in Plants. Molecular Physiology and Ecophysiology of Sulfur. Proceedings of the International Plant Sulfur Workshop). Seeds were sown in small trays containing vermiculite for better germination. Ten day old seedlings were transplanted to pots $(17 \mathrm{~cm} \times 20 \mathrm{~cm})$ containing sand, perlite, and vermiculite in 
a 2:1:1 ratio. The experimental unit consisted in a pot with two plants. There were two groups (LS and HS) of five pots for each genotype. For the initial establishment, the transplanted seedlings were fertilized once with 20:20:20 (N:P:K; Plant Prod, Brampton, ON, Canada) before the actual sulfur treatment. The nutrient solutions for the treatment were made fresh from stock solutions and applied once weekly. The LS nutrient solution contained $0.2 \mathrm{mM}$ $\mathrm{K}_{2} \mathrm{SO}_{4}$ and $1.8 \mathrm{mM} \mathrm{MgCl}_{2}$; HS contained $0.2 \mathrm{mM} \mathrm{K}_{2} \mathrm{SO}_{4}$ and $1.8 \mathrm{mM} \mathrm{MgSO}_{4}$. Other nutrients included $4.5 \mathrm{mM} \mathrm{Ca}\left(\mathrm{NO}_{3}\right)_{2}$, $1.7 \mathrm{mM} \mathrm{K}_{2} \mathrm{HPO}_{4}, 4 \mu \mathrm{M} \mathrm{MnSO}_{4} \cdot \mathrm{H}_{2} \mathrm{O}, 5 \mu \mathrm{M} \mathrm{H}_{3} \mathrm{BO}_{3}, 10 \mu \mathrm{M} \mathrm{Fe}-$ EDTA, $0.25 \mu \mathrm{M} \mathrm{CuSO}_{4} .5 \mathrm{H}_{2} \mathrm{O}, 1 \mu \mathrm{M} \mathrm{ZnSO} 4.7 \mathrm{H}_{2} \mathrm{O}$, and $0.2 \mu \mathrm{M}$ $\mathrm{Na}_{2} \mathrm{MoO}_{4} \cdot 2 \mathrm{H}_{2} \mathrm{O}$. Plants were grown in cabinets (Conviron $\mathrm{E} 8 \mathrm{H}$, Winnipeg, MB, Canada) with $16 \mathrm{~h}$ light (300-400 $\mu \mathrm{mol}$ photons $\left.\mathrm{m}^{-2} \mathrm{~s}^{-1}\right)$ and $8 \mathrm{~h}$ dark, with a temperature cycling between 18 and $24^{\circ} \mathrm{C}$ (Pandurangan et al., 2012).

\section{FIELD TRIAL}

The response of SARC1 and SMARC1N-PN1 genotypes to sulfur fertilization was assessed in a field trial conducted at the Cereal Research Centre Morden, MB, Canada, in 2012. Soil was sampled in the fall 2011 and analyzed at Exova, Calgary, AB, Canada, to determine the amount of nutrients needed for the treatment. Nutrient analysis found 24:129:1345 $\mathrm{kg} \mathrm{ha}^{-1}$ as nitrogen, phosphorus, potassium, and $47 \mathrm{~kg} \mathrm{ha}^{-1}$ as sulfur. Crops were either grown with or without applied sulfur $\left(30 \mathrm{~kg} \mathrm{ha}^{-1}\right)$ as gypsum $\left(\mathrm{CaSO}_{4} \cdot 2 \mathrm{H}_{2} \mathrm{O}\right)$. Recommended seed rate $(250,000$ seeds $\mathrm{ha}^{-1}=25$ seed $\mathrm{m}^{-2}$ ) and cultural practices were used at all plots. Plot size was $1 \mathrm{~m} \times 5.5 \mathrm{~m}$ trimmed to $5.0 \mathrm{~m}^{2}$ with spacing of two rows at $0.5 \mathrm{~m}$ between plots. All plots were planted in a randomized complete block design with four replications for each treatment, each replication consisting of two rows of $5.5 \mathrm{~m}$ long accounting for 550 seeds per treatment. Two adjacent rows represented one replicate. A post emergent herbicide, Basagran (BASF Canada, Mississauga, ON, Canada) was applied at the rate of 2.21 $\mathrm{ha}^{-1}$. Fertilizer added in all the treatment plots was $120 \mathrm{~kg} \mathrm{~N} \mathrm{ha}^{-1}$. Dry mature seeds from the net area of each plot were harvested separately, weighed, and recorded as seed yield $\left(\mathrm{kg} \mathrm{ha}^{-1}\right)$.

\section{AMINO ACID ANALYSIS}

Extraction and quantification of sulfur amino acids from mature seed tissue was performed as previously described, using HPLC after derivatization with phenylisothiocyanate (HernándezSebastià et al., 2005; Taylor et al., 2008). Cysteine was quantified separately as cysteic acid after oxidation with performic acid.

\section{ALBUMIN AND GLOBULIN EXTRACTION AND QUANTIFICATION}

Albumin and globulin fractions were extracted from mature seed as described by Rolletschek et al. (2005). Protein in the extracts was quantified using the Bio-Rad Protein Assay reagent (Mississauga, ON, Canada) with bovine serum albumin as standard. Protein concentration was normalized according to the volume of extract recovered. A volume of sample equivalent to the same weight of tissue extracted was subjected to SDS-PAGE on a $12 \%$ polyacrylamide gel. Following staining with Coomassie R-250, band intensities in globulin extracts were measured with Quantity One 4.2.1 (Bio-Rad). Quantity One is very tolerant of an assortment of electrophoretic artifacts, and can measure total and average quantities, determine relative and actual amounts of protein. Prior to quantification the image acquired from scanning the gels was optimized by the software by performing lane background subtraction to reduce any noise or background density while maintaining image quality followed by filtering to remove small noise features while leaving larger features relatively unaffected. The software was used for identifying lanes and defining, quantitating, and matching bands. Lane-based quantitation used to calculate intensity of similar bands across lanes involves calculating the average intensity of pixels across the band width and integrating over the band height. The quantity of a band as measured by the area under its intensity profile curve is expressed as intensity $\times \mathrm{mm}$. Apparent molecular mass was calculated based on standards using the same software.

\section{SAMPLE PREPARATION AND MASS SPECTROMETRY}

Proteomic experiments were performed at the London Regional Proteomics Centre of the University of Western Ontario. Sample preparation was carried out at the Functional Proteomics Facility. Protein bands of interest identified by band intensities in the globulin extracts were excised by the robotic Ettan Spot Picker (GE Healthcare Life Sciences, Baie d'Urfé, QC, Canada) and suspended in 50\% methanol and 5\% acetic acid for digestion. Trypsin digestion was performed using the MassPREP automated digester (Waters, Mississauga, ON, Canada). Gel pieces were destained using $50 \mathrm{mM}$ ammonium bicarbonate and 50\% acetonitrile followed by protein reduction with $10 \mathrm{mM}$ dithiothreitol, alkylation with $55 \mathrm{mM}$ iodoacetamide and tryptic digestion. Peptides were extracted using a solution of $1 \%$ formic acid and $2 \%$ acetonitrile and lyophilized. Peptides were dissolved in a solution of $30 \%$ acetonitrile and $0.1 \%$ trifluoroacetic acid mixed with $\alpha$-cyano-4hydroxycinnamic acid in 50\% acetonitrile, $12.5 \mathrm{mM}$ ammonium citrate, $0.1 \%$ trifluoroacetic acid, and analyzed on a 4700 Proteomics Discovery System (Life Technologies, Burlington, ON, Canada) at the MALDI-MS facility. MS analysis was carried out in an $\mathrm{m} / \mathrm{z}$ range of $500-3500$ and mass tolerance of $50 \mathrm{ppm}$. Data acquisition and processing were done using 4000 Series Explorer and Data Explorer (Life Technologies). The instrument was equipped with a $355 \mathrm{~nm} \mathrm{Nd:YAG} \mathrm{laser} \mathrm{and} \mathrm{the} \mathrm{laser} \mathrm{rate} \mathrm{was}$ $200 \mathrm{~Hz}$. Reflectron and linear positive ion modes were used. Each mass spectrum was collected as a sum of 1000 shots. Samples from protein bands no. 1, 4, and 5 were further analyzed by LC-MSMS at the Biological Mass Spectrometry Laboratory. They were reconstituted in $18 \mu \mathrm{l}$ of $0.1 \%$ formic acid in water and $10 \mu \mathrm{l}$ was injected into the UPLC-MS/MS system. The system was comprised of a Waters nanoAcquity UPLC with a Waters C18 trapping and Waters $25 \mathrm{~cm}$ analytical column coupled to a Waters QToF Ultima Global Mass Spectrometer. The sample was run at a flow rate of $0.3 \mu \mathrm{l} / \mathrm{min}$. Solvent A was water:formic acid $0.1 \%$ and solvent B was acetonitrile:formic acid $0.1 \%$. Solvent B was set to go from $5 \%$ to $60 \%$ in $40 \mathrm{~min}$ and then reach $95 \%$ by $42.5 \mathrm{~min}$. B was kept at $95 \%$ for $5 \mathrm{~min}$ and brought back to $5 \%$ at $50 \mathrm{~min}$. The column was re-equilibrated for $25 \mathrm{~min}$ prior to the following injection. Sample loading took $3 \mathrm{~min}$ with a flow rate of $10 \mu \mathrm{l} / \mathrm{min}$ at $99 \%$ $\mathrm{A}$ and $1 \% \mathrm{~B}$. MS survey scan was performed at a cone voltage of $35 \mathrm{~V}$ and set to $1.4 \mathrm{~s}$ with $0.1 \mathrm{~s}$ interscan and recorded from 300 to $1800 \mathrm{~m} / \mathrm{z}$. In a given survey scan, all doubly and triply charged 
ions with intensities greater than 40 counts were considered candidate to undergo MS/MS fragmentation. MS/MS acquisition would stop as soon as the total ion current would reach 25000 counts per second or after a maximum time of $6 \mathrm{~s}$. MS/MS scan was acquired from 50 to $1800 \mathrm{~m} / z$ for $1.4 \mathrm{~s}$ with an interscan time of $0.1 \mathrm{~s}$. Selected ions were fragmented with a collision energy of $30 \mathrm{eV}$.

Peptide mass fingerprint data were analyzed by searching peptide mass values against a translated version of the preliminary release of the common bean genome (June 26, 2012; Schmutz et al., 2014) using MASCOT (Matrix Science, Boston, MA, USA). The following parameters were used: 1 missed cleavage; fixed carbamidomethyl alkylation of cysteine; variable oxidation of methionine; peptide mass tolerance: $\pm 1.2 \mathrm{Da}$; peptide charge state: +1 , significant threshold: $p<0.05$. For MS-MS, raw data were converted to mgf files using PEAKS 5.3 (Bioinformatics Solutions Inc., Waterloo, ON, Canada). MS/MS ion search was performed with MASCOT against the same database, as well the Mascot database (MSDB, August 31, 2006) using similar cleavage and post-translational modification parameters.

\section{SULFATE ANALYSIS}

Replicate samples ( $\sim 50$ seeds) were ground to a fine powder in a Kleco Ball Mill (Visalia, CA, USA) and lyophilized. Approximately $100 \mathrm{mg}$ of ground tissue was used for sulfate analysis by chemical suppression ion chromatography and conductivity detection using a Dionex DX-600 Ion Chromatograph (Thermo Fisher Scientific, Sunnyvale, CA, USA), as described in Herschbach et al. (2000) with modifications. Approximately $100 \mathrm{mg}$ of tissue was extracted in $0.5 \mathrm{ml}$ of deionized water. The suspension was centrifuged at $16,000 \times g$ for $10 \mathrm{~min}$ at $4^{\circ} \mathrm{C}$. A $300 \mu \mathrm{l}$ aliquot of the cleared supernatant was transferred to an ion chromatography vial for testing using an IonPac anion-exchange column (AS14A, 4 mm; Thermo Fisher Scientific) and eluted with a mixture of $3.5 \mathrm{mM}$ sodium hydrogen carbonate, and $1.0 \mathrm{mM}$ sodium carbonate. A $10 \mu$ l aliquot of the solution contained in vials was injected into the eluent stream and background conductivity of eluents reduced by a suppressor (Anion Self-Regenerating Suppressor Ultra, $4 \mathrm{~mm}$ ). An AS50 auto sampler equipped with a refrigerated chamber was used to house the vials and Dionex Peaknet 6.0 software was employed to track and analyze data.

\section{ELEMENTAL ANALYSIS}

Approximately $500 \mathrm{mg}$ of ground seed tissue was submitted to elemental analysis which was performed by dry combustion with a CNS-2000 Elemental Analyzer (LECO Instruments ULC, Mississauga, ON, Canada) as described by Taylor et al. (2008).

\section{STATISTICAL ANALYSIS}

Analysis of variance was performed using SAS version 9.2 (Toronto, ON, Canada). Homogeneity of the variances was inspected by residual graphic analysis.

\section{ACCESSION NUMBERS}

Accession numbers for proteins in this study are as follows: arcelinlike 4 [Uniprot:Q8RVX7]; lipoxygenase-3 [Phytozome:Phvul.005g 157000.1]; albumin-2 [Phytozome:Phvul007g275800]; $\alpha$-amylase inhibitor $\beta$-subunit [Uniprot:Q9S9E1]; $\alpha$-amylase inhibitor 1 [Uniprot:Q6J2U4].

\section{RESULTS}

\section{INCREASED YIELD OF SMARC1N-PN1 IN RESPONSE TO HIGH SULFUR} UNDER CONTROLLED CONDITIONS

To determine whether differences in response to sulfur nutrition are associated with the presence of an additional, endogenous sink for sulfur in SMARC1N-PN1, an experiment was performed under controlled conditions with two levels of sulfate fertilization. Treatment conditions were designed so that the LS conditions correspond to a sulfur deficiency at the reproductive stage. The LS condition was found to be non-limiting for vegetative growth (Figure 1). The nitrogen levels selected are non-limiting (Sánchez et al., 2002; Chiaiese et al., 2004). The two genotypes were compared for their agronomic parameters. The following variables were evaluated: number of seeds, seed weight, and seed yield (Table 2). The fact that SARC1 and SMARC1N-PN1 are not completely isogenic explains the occurrence of genotypic differences for some of these characteristics. There were significant interactions between factors for seed weight and yield. Whereas the average seed weight decreased under HS for SARC1, it actually increased for SMARC1N-PN1 ( $\mathrm{G} \times \mathrm{T} ; p \leq 0.01)$. This was associated with increased yield, specifically in SMARC1N-PN1, by $8 \%$ $(\mathrm{G} \times \mathrm{T} ; p \leq 0.05)$. A trial was performed to determine if the differences observed under controlled conditions would be replicated in the field. The large difference in yield between genotypes indicates that SMARC1N-PN1 is not well adapted to agronomic conditions in Manitoba. Both genotypes exhibited a limited yield response to sulfate fertilization, by $3-15 \%$ (Table 3). This response is typical for common bean and other legume crops.

\section{INCREASED SEED CONCENTRATION OF SULFUR AND SULFATE IN RESPONSE TO HIGH SULFATE TREATMENT}

To determine if the sulfur treatment effectively altered seed composition and particularly the concentration of sulfur and its metabolites, mature seeds were analyzed for total carbon, nitrogen,

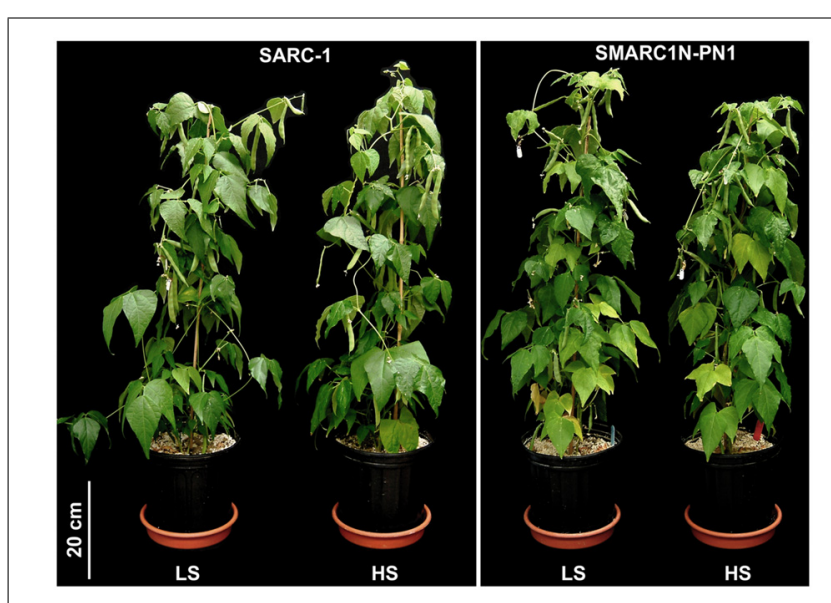

FIGURE 1 | Plants grown under controlled conditions with low sulfur (LS) and high sulfur (HS), 60 days after germination and 26 days after flowering. Vegetative growth appeared similar between genotypes. 
Table 2 | Effect of sulfur on number of seeds, seed weight, and yield under controlled conditions.

\begin{tabular}{lllll}
\hline Genotype & Treatment & $\begin{array}{l}\text { Number } \\
\text { of seeds }\end{array}$ & $\begin{array}{l}\text { Seed } \\
\text { weight (mg) }\end{array}$ & Yield (g) \\
\hline SARC1 & LS & $134 \pm 16$ & $214.6 \pm 10.1$ & $28.6 \pm 2.1$ \\
& HS & $143 \pm 9$ & $196.9 \pm 8.9$ & $28.2 \pm 1.5$ \\
SMARC1N-PN1 & LS & $152 \pm 12$ & $195.5 \pm 9.0$ & $29.6 \pm 1.2$ \\
& HS & $157 \pm 9$ & $203.8 \pm 11.8$ & $32.0 \pm 0.7$ \\
\hline Source of variation & d. f. & & ANOVA $\boldsymbol{p}$-value \\
\hline Genotype (G) & 1 & 0.008 & n. s. & 0.002 \\
Treatment (T) & 1 & n. s. & n. s. & n. s. \\
G $\times$ T & 1 & n. s. & 0.01 & 0.05 \\
Error & 15 & & & \\
\hline
\end{tabular}

Values are the average $\pm S D ; n=5 ; L S$, low sulfur $\left(0.2 \mathrm{mM} \mathrm{SO}_{4}\right) ; H S$, high sulfur $\left(2 \mathrm{mM} \mathrm{SO}_{4}\right)$; d. f., degrees of freedom; n. s., not significant.

Table 3 | Seed yield in sulfur deficient and -sufficient field conditions.

\begin{tabular}{lll}
\hline Genotype & $\begin{array}{l}\text { Yield without } \\
\text { sulfur }\left(\mathbf{k g ~ h a} \mathbf{~}^{\mathbf{- 1}}\right)\end{array}$ & $\begin{array}{l}\text { Yield with } \\
\text { sulfur }(\mathbf{k g ~ h a}\end{array}$ \\
\hline SARC1
\end{tabular}

Values are the average $\pm S D ; n=4$.

and sulfur by elemental analysis and for sulfate concentration by ion analysis. Previously, SARC1 and SMARC1N-PN1 were shown to have similar nitrogen concentration in seed (Hartweck and Osborn, 1997), and Taylor et al. (2008) reported a similar seed concentration of carbon, nitrogen, and sulfur. The sulfur treatment did not change carbon and nitrogen concentration, but had a significant effect on sulfur and sulfate concentration (Table 4). Sulfur concentration was raised by the HS treatment by approximately 15 to $20 \%$ in both genotypes. Sulfate concentration was increased by $17 \%$ in SARC1 and $38 \%$ in SMARC1N-PN1. The differences in sulfur and sulfate concentrations indicate that treatment conditions are suitable to investigate whether the two genotypes respond differently to sulfur nutrition.

\section{INCREASED CONCENTRATION OF CYSTEINE AND GLOBULINS IN SMARC1N-PN1 UNDER HIGH SULFATE CONDITIONS}

To evaluate whether sulfur nutrition has an effect on the total concentration of sulfur amino acids, methionine, cysteine, and the non-protein amino acid, $S$-methylcysteine were quantified after acid hydrolysis of ground seed tissue. As expected, the concentration of these three amino acids was different between genotypes, methionine, and cysteine being higher, and $S$-methylcysteine lower in SMARC1N-PN1 than in SARC1 (Table 5), as previously reported (Taylor et al., 2008). HS increased the levels of $S$-methylcysteine by approximately $40 \%$ in both genotypes. Cysteine concentration was raised in response to the
HS treatment specifically in SMARC1N-PN1, by $16 \%(\mathrm{G} \times \mathrm{T}$; $p \leq 0.03)$. On average, the combined levels of methionine and cysteine were elevated by $13 \%$ in SMARC1N-PN1, while they were decreased by $2 \%$ in SARC1 in response to the HS treatment.

To investigate whether the differences in sulfur nutrient allocation influenced seed storage protein composition, an important determinant of seed quality, albumins, and globulins were sequentially extracted and their concentration quantified (Table 6). The concentration of extractible albumins was unchanged by the treatment. However, the concentration of extractible globulins increased specifically in SMARC1N-PN1, by $24 \%(\mathrm{G} \times \mathrm{T}$; $p \leq 0.008$ ).

The globulin extracts were analyzed by SDS-PAGE. A volume of sample equal to a similar weight of seed tissue extracted was separated by electrophoresis (Figure 2). The volume of five protein bands appeared to be increased by the sulfur treatment. This was confirmed by image analysis with Quantity One (Table 7). The fold change and statistical significance of the changes was confirmed by analyzing replicate extracts of each genotype on separate gels (Supplementary Figure S1; Supplementary Tables S1 and S2). The protein bands were excised, digested with trypsin and analyzed by MALDI-MS or LC-MS-MS and identified by MASCOT search against the MASCOT database, or a translated database of the common bean genome (Schmutz et al., 2014). Protein bands no. 2 and 3 could be identified by MALDI-MS, whereas protein bands no. 1, 4, and 5 required more sensitive LC-MS-MS analysis. Tables 8 and 9 provide information about protein identifications and list the number of methionine, cysteine, and total residues in each protein. In all cases, the apparent molecular mass measured by electrophoresis matched the predicted molecular mass relatively closely.

Protein band no. 2 was identified as a lipoxygenase, which was named lipoxygenase-3, based on its similarity to the corresponding soybean and pea proteins. Its baseline levels were higher in SMARC1N-PN1 than in SARC1 by approximately twofold. These results are consistent with the prior identification of this lipoxygenase as elevated in SMARC1N-PN1 as compared with SARC1, both by spectral counting (1.6-fold) and immunoblotting (2.5-fold; Marsolais et al., 2010). This protein had been identified on the basis of the soybean lipoxygenase3 sequence (Yenofsky etal., 1988). The common bean accession shares $88 \%$ identity with soybean lipoxygenase-3, and $84 \%$ identity with pea lipoxygenase-3 (Ealing and Casey, 1988). Lipoxygenase-3 levels were increased by the sulfur treatment by approximately twofold. This was observed exclusively in SMARC1N-PN1. The apparent molecular mass determined for lipoxygenase-3 is consistent with the fact that the pea lipoxygenase A1 polypeptide, whose $\mathrm{N}$-terminal sequence matched the deduced amino acid sequence of the lipoxygenase- 3 cDNA, had an apparent molecular mass greater than 97.4 $\mathrm{kDa}$ (Domoney et al., 1990). Lipoxygenase-3 is particularly rich in sulfur amino acids with $1.7 \%$ of its residues as methionine and $0.5 \%$ as cysteine.

Protein band no. 3 was identified as albumin-2. Its baseline levels were sixfold higher in SMARC1N-PN1 than in SARC1. These results are consistent with the prior identification of albumin-2 
Table 4 | Elemental and sulfate concentrations in mature seed.

\begin{tabular}{|c|c|c|c|c|c|}
\hline Genotype & Treatment & C (\%) & N (\%) & $\mathbf{S}(\%)$ & $\mathrm{SO}_{4}{ }^{2-}(\mathrm{nmol} / \mathrm{mg})$ \\
\hline SARC1 & LS & $46.4 \pm 0.2$ & $3.90 \pm 0.11$ & $0.20 \pm 0.12$ & $0.18 \pm 0.03$ \\
\hline \multirow[t]{2}{*}{ SMARC1N-PN1 } & LS & $46.0 \pm 0.1$ & $3.63 \pm 0.20$ & $0.19 \pm 0.01$ & $0.21 \pm 0.05$ \\
\hline & $\mathrm{HS}$ & $46.0 \pm 0.1$ & $3.71 \pm 0.14$ & $0.23 \pm 0.01$ & $0.29 \pm 0.02$ \\
\hline Genotype (G) & 1 & 0.0001 & 0.006 & n. s. & 0.002 \\
\hline Treatment (T) & 1 & n. s. & n. s. & 0.0001 & 0.001 \\
\hline$G \times T$ & 1 & n. s. & n. s. & n. s. & n. s. \\
\hline Error & 15 & & & & \\
\hline
\end{tabular}

Values are the average $\pm S D ; n=5$.

Table 5 | Sulfur amino acid concentration in mature seed.

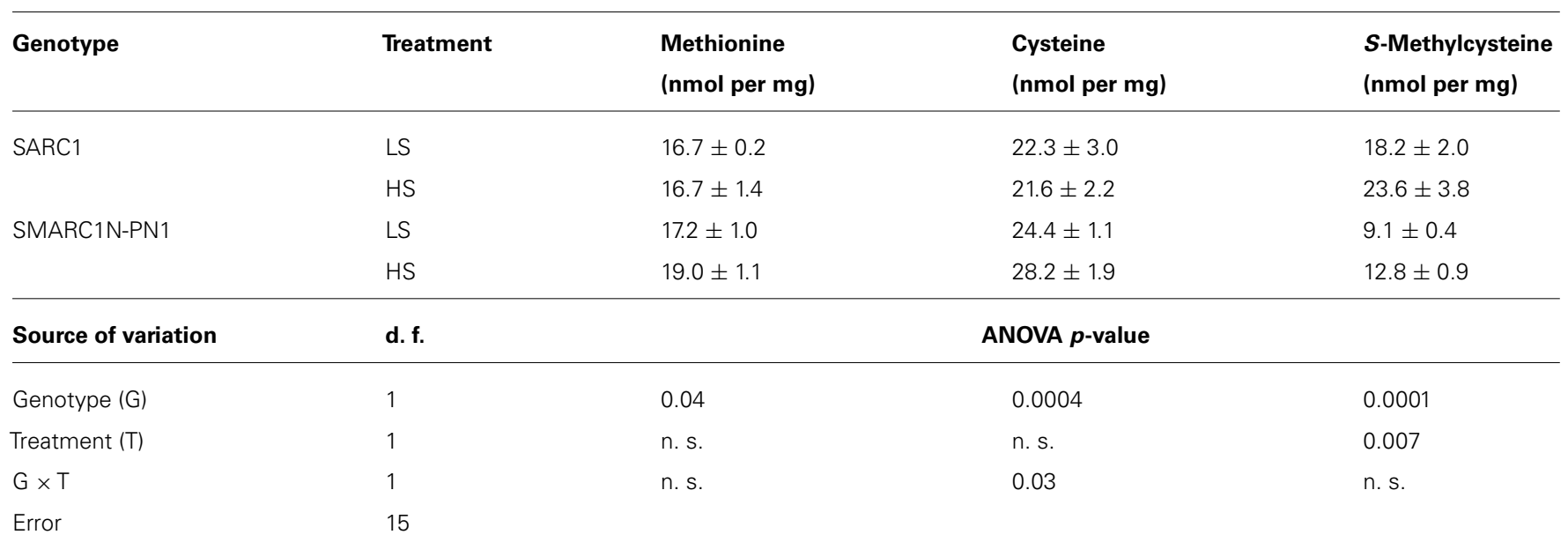

Values are the average $\pm S D ; n=3 ; n=5$ for cysteine.

as being elevated by about 10-fold in SMARC1N-PN1 as compared with SARC1 according to two-dimensional electrophoresis based proteomics (Marsolais et al., 2010). This protein had been identified by de novo sequencing, on the basis of its similarity with pea albumin-2 (Higgins et al., 1987) and mung bean seed albumin [Uniprot:Q43680], and its full-length cDNA had been subsequently cloned (Yin et al., 2011). Its transcript levels were elevated in developing seeds of SMARC1N-PN1 as compared with SARC1 (Liao et al., 2012). Albumin-2 levels were increased by the HS treatment in both genotypes, by approximately $20-30 \%$. The sequence of albumin- 2 is relatively rich in sulfur amino acids, with $0.9 \%$ of its residues as methionine and $1.3 \%$ as cysteine.

Protein band no. 1 was identified as arcelin-like protein 4 (Lioi et al., 2003). It was only present in the SARC1 extracts. This is consistent with previous spectral counting and two-dimensional electrophoresis based proteomic data (Marsolais et al., 2010). Arcelin-like protein 4 contains $0.4 \%$ its residues as methionine and $0.8 \%$ as cysteine. Protein bands no. 4 and 5 were only observed in SMARC1N-PN1. They were identified as $\alpha$-amylase inhibitor $\beta$ subunit (Kasahara et al., 1996). The levels of this protein had been shown to be elevated by 20-fold in SMARC1N-PN1 as compared with SARC1 by spectral counting, and this had been validated by two-dimensional electrophoresis based proteomics (Marsolais et al., 2010). The apparent molecular mass measured for protein band no. 4 is in agreement with the results obtained with $\alpha$ amylase inhibitor purified from Great Northern beans (Furuichi et al., 1993). A protein band of $15.5 \mathrm{kDa}$ had been identified as the $\beta$ subunit by $\mathrm{N}$-terminal sequencing and appeared not to be glycosylated. Protein band no. 5 is likely be a minor form of the $\alpha$-amylase inhibitor $\beta$ subunit lacking one or more residues at the $\mathrm{C}$-terminal. Indeed, a peptide containing the sequence of the $\mathrm{N}$ terminus was detected for this band. In the work by Furuichi et al. (1993) a protein band of $13.5 \mathrm{kDa}$ band was tentatively assigned as the $\alpha$ subunit and appeared to be glycosylated. Here, the proteomic data were unambiguous and did not identify a match to the $\alpha$ subunit. Interestingly, the $\alpha$ subunit was conspicuously absent from the SMARC1N-PN1 proteome determined by spectral counting (Marsolais et al., 2010). Purification of the $\beta$ subunit yielded a complex with the $\alpha$-amylase inhibitor like protein, with a predicted molecular mass of $25 \mathrm{kDa}$, in which the $\alpha$ subunit was 
Table 6 | Concentration of extractible albumins and globulins in mature seed.

\begin{tabular}{llll}
\hline Genotype & Treatment & Albumins (\%) & Globulins (\%) \\
\hline SARC1 & LS & $1.79 \pm 0.25$ & $3.01 \pm 0.51$ \\
SMARC1N-PN1 & HS & $1.88 \pm 0.10$ & $2.71 \pm 0.21$ \\
& HS & $1.95 \pm 0.11$ & $3.59 \pm 0.57$ \\
Source of variation & d. f. & \multicolumn{2}{c}{ ANOVA $\boldsymbol{p}$-value } \\
\hline Genotype (G) & 1 & n. s. & 0.0001 \\
Treatment (T) & 1 & n. s. & n. s. \\
G $\times$ T & 1 & n. s. & 0.008 \\
Error & 15 & & \\
\hline
\end{tabular}

Values are the average $\pm S D ; n=5$.

absent (Yin and Marsolais, unpublished results). The apparent molecular mass of this complex measured by size exclusion chromatography was equal to $41.2 \mathrm{kDa}$. In SDS-PAGE, the purified fraction contained a minor band of approximately $13.8 \mathrm{kDa}$, similar to the results in Figure 2. The $\alpha$-amylase inhibitor $\beta$ chain is devoid of sulfur amino acids. However, the corresponding $\alpha$ amylase- 1 precursor contains $1.6 \%$ of its residues as methionine

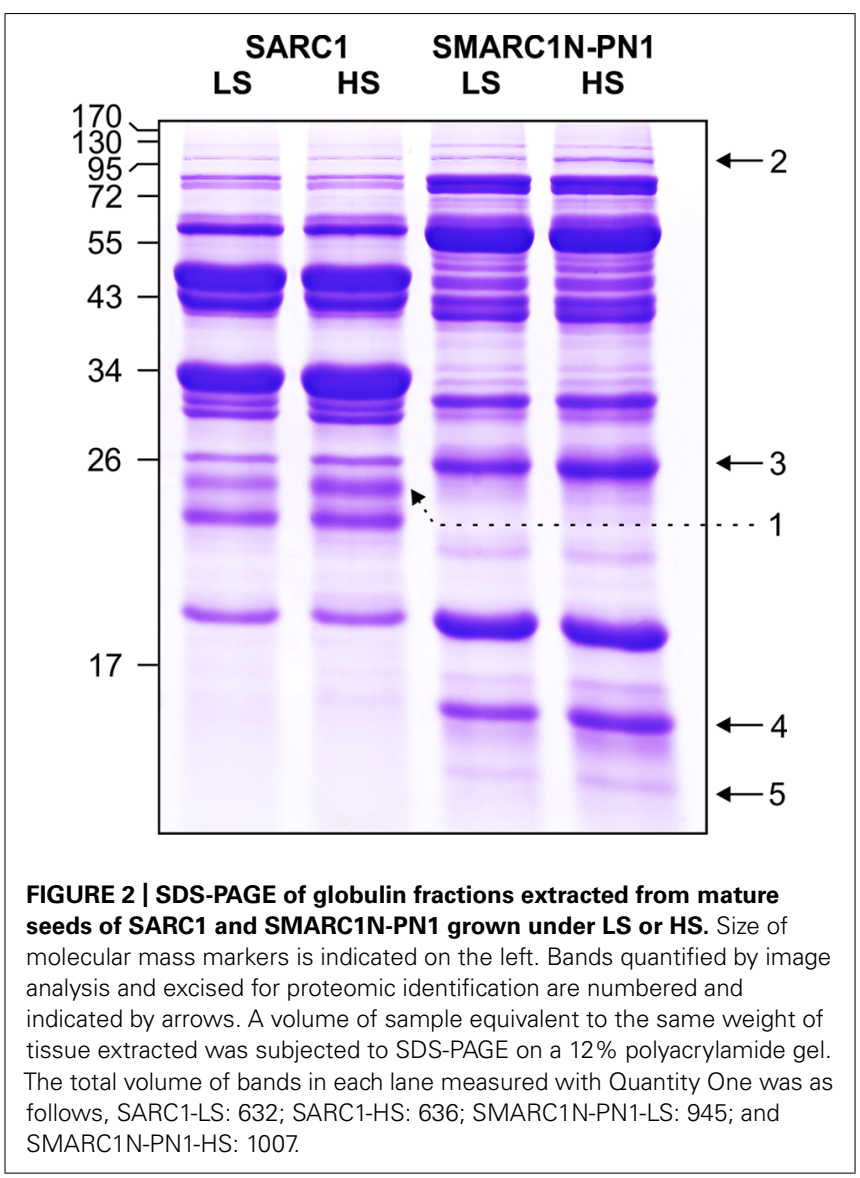

without any cysteine (Prescott et al., 2005). The four methionines are located at the N-terminus of the polypeptide precursor. Sulfur amino acid residues are neither present in the $\alpha$ subunit (Kasahara et al., 1996).

\section{DISCUSSION}

The most important finding reported from this study is that the protein pool of SMARC1N-PN1 was able to accommodate an increase in sulfur amino acids, particularly cysteine, in response to enhanced sulfate nutrition, whereas this was not the case in SARC1. This property is associated with the presence of an endogenous sink for sulfur in SMARC1N-PN1. The increase in cysteine concentration was associated with a specific increase in the concentration of extractible globulins and seed yield in SMARC1N-PN1. It has been reported that sulfur nutrition influences the response of chickpea plants to the transgenic expression of sunflower seed albumin (Chiaiese et al., 2004). An increase in the seed concentration of reduced sulfur was more pronounced in the transgenic line than in wild-type under conditions of low nitrogen and high sulfur nutrition. Further results were suggestive of a higher methionine concentration in the transgenic line in response to high sulfur and high nitrogen, although this could not be analyzed statistically due to a lack of replication. Recently, Kim et al. (2014) reported that adequate sulfate nutrition is required to maximize the accumulation of maize $\delta$-zein in transgenic soybean lines where expression of the endogenous $\beta$-conglycinin was suppressed by RNA interference.

The seed concentration of sulfate reported here for common bean is much lower than the concentration of oxidized sulfur in lupin or pea, by approximately 100-fold (Tabe and Droux, 2002; Chiaiese etal., 2004). Whereas in lupin or pea, sulfate represents a reserve of sulfur, whose levels can be significantly reduced upon transgenic expression of a sulfur-rich protein, $S$ methylcysteine plays a similar role in common bean. This is supported by the fact that the $S$-methylcysteine concentration was reduced by approximately twofold in SMARC1N-PN1 as compared with SARC1. However, the effect of sulfur nutrition on the concentration of $S$-methylcysteine was similar between genotypes. Likewise in chickpea, nitrogen and sulfur treatments had a similar effect on oxidized sulfur concentration in wild-type and a transgenic line expressing sunflower seed albumin (Chiaiese et al., 2004).

The increase in the extractible globulin fraction associated with enhanced levels of cysteine stimulated an analysis of sulfurresponsive proteins in the extracts. Two lectins, uniquely present in either genotype, arcelin-like protein 4 , and the $\beta$ subunit of the $\alpha$-amylase inhibitor, were identified as sulfur-responsive. In the case of the $\alpha$-amylase inhibitor, sulfur is needed for the accumulation of the polypeptide precursor but not the mature $\beta$ subunit. Albumin-2 was found to be increased by a similar fold change in response to HS in both genotypes, although its baseline levels were higher in SMARC1N-PN1. In pea, albumin-2 levels were initially found to be reduced in response to severe sulfur deficiency (Randall et al., 1979). In later work, protein levels were found to be relatively unchanged in response to moderate sulfur deficiency (Higgins et al., 1987). Albumin-2 is characterized by the presence of four repeats of the hemopexin domain. The results 
Table 7 | Quantification and apparent molecular mass of sulfur-responsive protein bands identified in Figure 2.

\begin{tabular}{|c|c|c|c|c|c|c|c|}
\hline \multirow{2}{*}{$\begin{array}{l}\text { Protein } \\
\text { band no. }\end{array}$} & \multirow{2}{*}{$\begin{array}{l}\text { Apparent molecular } \\
\text { mass (kDa) }\end{array}$} & \multicolumn{3}{|c|}{ SARC1 } & \multicolumn{3}{|c|}{ SMARC1N-PN1 } \\
\hline & & \multicolumn{2}{|c|}{ Volume } & Increase (\%) & \multicolumn{2}{|c|}{ Volume } & Increase (\%) \\
\hline 1 & 25.0 & 29.7 & 44 & 48 & - & - & - \\
\hline 2 & 105.4 & 6.30 & 6.54 & 4 & 12.4 & 24.9 & 101 \\
\hline 4 & 15.7 & - & - & - & 83.2 & 110 & 32 \\
\hline 5 & 13.8 & - & - & - & 9.64 & 13.1 & 36 \\
\hline
\end{tabular}

Table 8 | Identification of protein bands in Figure 2 by MALDI-MS and MASCOT search following trypsin digestion.

\begin{tabular}{|c|c|c|c|c|c|c|c|c|}
\hline $\begin{array}{l}\text { Protein } \\
\text { band no. }\end{array}$ & Sample & Accession & $\begin{array}{l}\text { Predicted } \\
\text { mass (kDa) }\end{array}$ & $\begin{array}{l}\text { Protein } \\
\text { score }\end{array}$ & $p$-value & Matches & $\begin{array}{l}\text { Protein } \\
\text { coverage (\%) }\end{array}$ & $\begin{array}{l}\text { Residues vs. } \\
\text { Met vs. Cys }\end{array}$ \\
\hline 2 & SMARC1N-PN1-HS & Lox-3 & 97527 & 85 & 0.0006 & 27 & 25 & $860 / 15 / 4$ \\
\hline 3 & SMARC1N-PN1-LS & Alb-2 & 25574 & 83 & 0.0009 & 21 & 73 & $227 / 2 / 3$ \\
\hline 3 & SMARC1N-PN1-HS & Alb-2 & 25574 & 82 & 0.001 & 19 & 70 & $227 / 2 / 3$ \\
\hline
\end{tabular}

Lox-3, lipoxygenase-3; Alb-2, albumin-2. See section "Materials and Methods" for accession numbers.

Table 9 | Identification of protein bands in Figure 2 by MS-MS and MASCOT search following trypsin digestion.

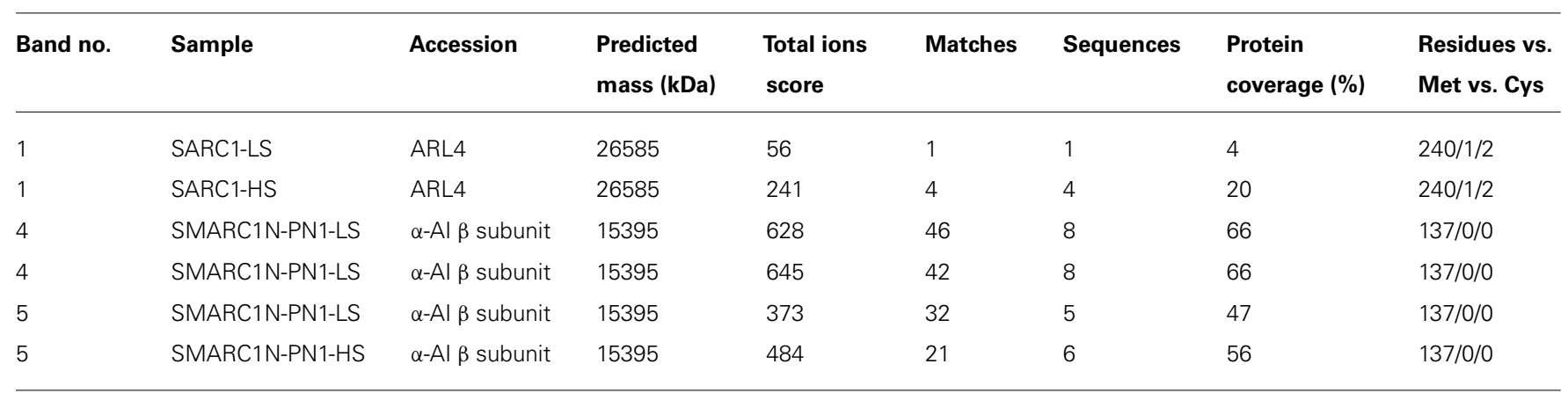

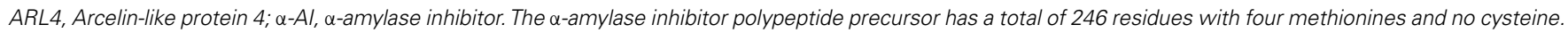

of crystallization studies have revealed that these proteins bind spermine (Gaur etal., 2010, 2011). Binding of heme and spermine was found to be mutually exclusive in grasspea hemopexin. A pea mutant lacking albumin-2 had altered levels of polyamines, and this was associated with increased seed protein concentration (Vigeolas et al., 2008). Whether SARC1 and SMARC1N-PN1 differ in their level of polyamines could be the subject of future investigation.

The identification of lipoxygenase-3 as a sulfur-responsive protein is particularly interesting, because this response was observed in only one of the genotypes. The present result strongly suggests that the sulfur-responsive albumin protein of $95 \mathrm{kDa}$ identified in pea is actually lipoxygenase-3 (Higgins et al., 1987). We speculate that differences in sulfur-responsiveness between the two common bean genotypes are probably determined by polymorphisms in the promoter or $3^{\prime}$-untranslated region of the lipoxygenase- 3 gene. These polymorphisms must arise from recombination at the lipoxygenase-3 locus between the different parents. If this is true, sequence comparisons between the two genotypes might lead to the identification of a much sought after cis-acting regulatory element determining a positive response to sulfur nutrition in higher plants. To date, the only known cis-acting regulatory motif determining a transcriptional response to sulfur, the SURE motif, is involved in the up-regulation of sulfate transporter and assimilatory genes in response to sulfur deficiency (Maruyama-Nakashita et al., 2005).

The present results have special implications for the agronomic management of common bean, if storage protein deficiency is used as a trait for the improvement of protein quality through conventional breeding. Although SARC1 and SMARC1N-PN1 responded equally to sulfate fertilization under field conditions, the results obtained under controlled conditions suggest that adequate sulfur 
nutrition is required to maximize the concentration of sulfur amino acids and therefore protein quality in genotypes lacking phaseolin and major lectins like SMARC1N-PN1. As deposition of sulfur due to atmospheric pollution decreases, sulfate fertilization might become necessary for common bean production in Southwestern Ontario. It is currently an integral part of agronomic production in the plains of Manitoba.

\section{ACKNOWLEDGMENTS}

We thank staff at the Southern Crop Protection and Food Research Centre, Igor Lalin for sulfate analysis, Tim McDowell for elemental analysis, Patrick Chapman for bioinformatics, and Alex Molnar for graphics. We are grateful to staff at the London Regional Proteomics Centre, Paula Pittock and Kristina Jurcic. We acknowledge Rey Interior, at the SPARC BioCentre, Hospital for Sick Children, for help with amino acid analyses. We thank Larry Stitt of LW Stitt Statistical Services for help with statistical interpretations. We are indebted to Cynthia Grant at the Brandon Research Centre of Agriculture and Agri-Food Canada, for advice on field sulfur trials, and to Derek Lydiate at the Saskatoon Research Centre of Agriculture and Agri-Food Canada, for discussions that stimulated this work. Steven Karcz of the Saskatoon Research Centre, who passed away in 2012, helped with MASCOT. This work was supported in part by a grant from the Ontario Research Fund for Research Excellence, Round 4 to FM (project 043), and grants from the Manitoba Pulse Growers Association, and Pulse Science Cluster of the AgriInnovation Program of Agriculture and Agri-Food Canada to AH and FM.

\section{SUPPLEMENTARY MATERIAL}

The Supplementary Material for this article can be found online at: http://www.frontiersin.org/journal/10.3389/fpls.2015.00092/ abstract

\section{REFERENCES}

Amir, R., Han, T., and Ma, F. (2012). Bioengineering approaches to improve the nutritional values of seeds by increasing their methionine content. Mol. Breed. 29, 915-924. doi: 10.1007/s11032-011-9690-7

Anderson, J. W., and Fitzgerald, M. A. (2001). Physiological and metabolic origin of sulphur for the synthesis of seed storage proteins. J. Plant Physiol. 158, 447-456. doi: 10.1078/0176-1617-00356

Aragão, F. J. L., Barros, L. M. G., De Sousa, M. V., Grossi De Sá, M. F., Almeida, E. R. P., Gander, E. S., et al. (1999). Expression of a methionine-rich storage albumin from the Brazil nut (Bertholletia excelsa HBK Lecythidaceae) in transgenic bean plants (Phaseolus vulgaris L. Fabaceae). Genet. Mol. Biol. 22, 445-449. doi: 10.1590/S1415-47571999000300026

Blagrove, R. J., Gillesie, J. M., and Randall, P. J. (1976). Effect of sulphur supply on the seed globulin composition of Lupinus angustifolius. Aust. J. Plant Physiol. 3 , 173-184. doi: 10.1071/PP9760173

Bourgis, F., Roje, S., Nuccio, M. L., Fisher, D. B., Tarczynski, M. C., Li, C. J., et al. (1999). S-Methylmethionine plays a major role in phloem sulfur transport and is synthesized by a novel type of methyltransferase. Plant Cell 11, 1485-1497. doi: 10.1105/tpc.11.8.1485

Buchner, P., Stuiver, C. E., Westerman, S., Wirtz, M., Hell, R., Hawkesford, M. J., etal. (2004). Regulation of sulfate uptake and expression of sulfate transporter genes in Brassica oleracea as affected by atmospheric H2S and pedospheric sulfate nutrition. Plant Physiol. 136, 3396-3408. doi: 10.1104/pp.104. 046441

Chandler, P. M., Higgins, T. J., Randall, P. J., and Spencer, D. (1983). Regulation of legumin levels in developing pea seeds under conditions of sulfur deficiency: rates of legumin synthesis and levels of legumin mRNA. Plant Physiol. 71, 47-54. doi: $10.1104 /$ pp.71.1.47
Chandler, P. M., Spencer, D., Randall, P. J., and Higgins, T. J. (1984). Influence of sulfur nutrition on developmental patterns of some major pea seed proteins and their mRNAs. Plant Physiol. 75, 651-657. doi: 10.1104/pp.7 5.3.651

Chiaiese, P., Ohkama-Ohtsu, N., Molvig, L., Godfree, R., Dove, H., Hocart, C., et al. (2004). Sulphur and nitrogen nutrition influence the response of chickpea seeds to an added, transgenic sink for organic sulphur. J. Exp. Bot. 55, 1889-1901. doi: 10.1093/jxb/erh198

De Kok, L. J., Stulen, I., and Hawkesford, M. J. (2011). "Sulfur nutrition in crop plants," in The Molecular and Physiological Basis of Nutrient Use Efficiency in Crops, eds M. J. Hawkesford and P. Barraclough (Chichester: Wiley-Blackwell), 295-309. doi: 10.1002/9780470960707.ch14

Demidov, D., Horstmann, C., Meixner, M., Pickardt, T., Saalbach, I., Galili, G., and Müntz, K. (2003). Additive effects of the feed-back insensitive bacterial aspartate kinase and the Brazil nut $2 \mathrm{~S}$ albumin on the methionine content of transgenic narbon bean (Vicia narbonensis L.). Mol. Breed. 11, 187-201. doi: 10.1023/A:1022814506153

Dinkins, R. D., Reddy, M. S. S., Meurer, C. A., Yan, B., Trick, H., Thibaud-Nissen, F., et al. (2001). Increased sulfur amino acids in soybean plants over expressing the maize $15 \mathrm{kDa}$ zein protein. In vitro Cell. Dev. Biol. Plant 37, 742-747. doi: 10.1007/s11627-001-0123-x

Domoney, C., Firmin, J. L., Sidebottom, C., Ealing, P. M., Slabas, A., and Casey, R. (1990). Lipoxygenase heterogeneity in Pisum sativum. Planta 181, 35-43. doi: 10.1007/BF00202322

Ealing, P. M., and Casey, R. (1988). The complete amino acid sequence of a pea (Pisum sativum) seed lipoxygenase predicted from a near full-length cDNA. Biochem. J. 253, 915-918.

Furuichi, Y., Takemura, M., Uesaka, N., Kamemura, K., Shimada, S., Komada, H., et al. (1993). Some characteristics of an $\alpha$-amylase inhibitor from Phaseolus vulgaris (cultivar Great Northern) seeds. Biosci. Biotechnol. Biochem. 57, 147-148. doi: $10.1271 /$ bbb. 57.147

Galili, G., and Amir, R. (2013). Fortifying plants with the essential amino acids lysine and methionine to improve nutritional quality. Plant Biotechnol. J. 11, 211-222. doi: 10.1111/pbi.12025

Gaur, V., Chanana, V., Jain, A., and Salunke, D. M. (2011). The structure of a haemopexin-fold protein from cow pea (Vigna unguiculata) suggests functional diversity of haemopexins in plants. Acta Crystallogr. Sect. F. Struct. Biol. Cryst. Commun. 67, 193-200. doi: 10.1107/s1744309110051250

Gaur, V., Qureshi, I. A., Singh, A., Chanana, V., and Salunke, D. M. (2010). Crystal structure and functional insights of hemopexin fold protein from grass pea. Plant Physiol. 152, 1842-1850. doi: 10.1104/pp.109.150680

Gayler, K. R., and Sykes, G. E. (1985). Effects of nutritional stress on the storage proteins of soybeans. Plant Physiol. 78, 582-585. doi: 10.1104/pp.78.3.582

Hanafy, M. S., Rahman, S. M., Nakamoto, Y., Fujiwara, T., Naito, S., Wakasa, K., et al. (2013a). Differential response of methionine metabolism in two grain legumes, soybean and azuki bean, expressing a mutated form of Arabidopsis cystathionine $\gamma$-synthase. J. Plant Physiol. 170, 338-345. doi: 10.1016/j.jplph.2012.10.018

Hanafy, M. S., Rahman, S. M., Nakamoto, Y., Fujiwara, T., Naito, S., Wakasa, K., et al. (2013b). Erratum to differential response of methionine metabolism in two grain legumes, soybean, and azuki bean, expressing a mutated form of Arabidopsis cystathionine $\gamma$-synthase. J. Plant Physiol. 170, 1469. doi: 10.1016/j.jplph.2013.06.003

Hartweck, L. M., and Osborn, T. C. (1997). Altering protein composition by genetically removing phaseolin from common bean seeds containing arcelin or phytohemagglutinin. Theor. Appl. Genet. 95, 1012-1017. doi: 10.1007/s001220050655

Hawkesford, M. J. (2000). Plant responses to sulphur deficiency and the genetic manipulation of sulphate transporters to improve S-utilization efficiency. J. Exp. Bot. 51, 131-138. doi: 10.1093/jexbot/51.342.131

Hawkesford, M. J. (2003). Transporter gene families in plants: the sulphate transporter gene family - redundancy or specialization? Physiol. Plant. 117, 155-163. doi: 10.1034/j.1399-3054.2003.00034.x

Hawkesford, M. J., and De Kok, L. J. (2006). Managing sulphur metabolism in plants. Plant Cell Environ. 29, 382-395. doi: 10.1111/j.1365-3040.2005.01470.x

Herman, E. M. (2014). Soybean seed proteome rebalancing. Front. Plant Sci. 5:437. doi: 10.3389/fpls.2014.00437

Hernández-Sebastià, C., Marsolais, F., Saravitz, C., Israel, D., Dewey, R. E., and Huber, S. C. (2005). Free amino acid profiles suggest a possible role for asparagine in the control of storage-product accumulation in developing seeds of low- and high-protein soybean lines. J. Exp. Bot. 56, 1951-1963. doi: 10.1093/jxb/eri191 
Herschbach, C., Van Der Zalm, E., Schneider, A., Jouanin, L., De Kok, L. J., and Rennenberg, H. (2000). Regulation of sulfur nutrition in wild-type and transgenic poplar over-expressing $\gamma$-glutamylcysteine synthetase in the cytosol as affected by atmospheric H2S. Plant Physiol. 124, 461-473. doi: 10.1104/pp.12 4.1.461

Higgins, T. J. V., Beach, L. R., Spencer, D., Chandler, P. M., Randall, P. J., Blagrove, R. J., et al. (1987). cDNA and protein sequence of a major pea seed albumin (PA 2: $\mathrm{Mr} \approx 26$ 000). Plant Mol. Biol. 8, 37-45. doi: 10.1007/BF00016432

Holowach, L. P., Madison, J. T., and Thompson, J. F. (1986). Studies on the mechanism of regulation of the mRNA level for a soybean storage protein subunit by exogenous L-methionine. Plant Physiol. 80, 561-567. doi: 10.1104/pp.80.2.561

Holowach, L. P., Thompson, J. F., and Madison, J. T. (1984). Effects of exogenous methionine on storage protein composition of soybean cotyledons cultured in vitro. Plant Physiol. 74, 576-583. doi: 10.1104/pp.74.3.576

Kasahara, K., Hayashi, K., Arakawa, T., Philo, J. S., Hara, S., and Yamaguchi, H. (1996). Complete sequence, subunit structure, and complexes with pancreatic $\alpha$-amylase of an $\alpha$-amylase inhibitor from Phaseolus vulgaris white kidney beans. J. Biochem. (Tokyo) 120, 177-183. doi: 10.1093/oxfordjournals.jbchem.a021381

Kelly, J. D., and Hefle, S. L. (2000). 2S Methionine-rich protein (SSA) from sunflower seed is an IgE-binding protein. Allergy 55, 556-560. doi: 10.1034/j.13989995.2000.00498.x

Kim, H., Hirai, M. Y., Hayashi, H., Chino, M., Naito, S., and Fujiwara, T. (1999). Role of $\mathrm{O}$-acetyl-L-serine in the coordinated regulation of the expression of a soybean seed storage-protein gene by sulfur and nitrogen nutrition. Planta 209, 282-289. doi: $10.1007 / \mathrm{s} 004250050634$

Kim, W. S., Chronis, D., Juergens, M., Schroeder, A. C., Hyun, S. W., Jez, J. M., et al. (2012). Transgenic soybean plants overexpressing O-acetylserine sulfhydrylase accumulate enhanced levels of cysteine and Bowman-Birk protease inhibitor in seeds. Planta 235, 13-23. doi: 10.1007/s00425-011-1487-8

Kim, W., Jez, J. M., and Krishnan, H. B. (2014). Effects of proteome rebalancing and sulfur nutrition on the accumulation of methionine rich $\delta$-zein in transgenic soybeans. Front. Plant Sci. 5:633 doi: 10.3389/fpls.2014.00633

Kim, W. S., and Krishnan, H. B. (2004). Expression of an 11 kDa methioninerich delta-zein in transgenic soybean results in the formation of two types of novel protein bodies in transitional cells situated between the vascular tissue and storage parenchyma cells. Plant Biotechnol. J. 2, 199-210. doi: 10.1111/j.14677652.2004.00063.x

Krishnan, H. B. (2005). Engineering soybean for enhanced sulfur amino acid content. Crop Sci. 45, 454-461. doi: 10.2135/cropsci2005.0454

Krishnan, H. B., Bennett, J. O., Kim, W., Krishnan, H. A., and Mawhinney, T. P. (2005). Nitrogen lowers the sulfur amino acid content of soybean (Glycine max [L.] Merr.) by regulating the accumulation of Bowman-Birk protease inhibitor. J. Agric. Food Chem. 53, 6347-6354. doi: 10.1021/jf050510i

Krishnan, H. B., Kerley, M. S., Allee, G. L., Jang, S., Kim, W. S., and Fu, C. J. (2010). Maize $27 \mathrm{kDa}$ gamma-zein is a potential allergen for early weaned pigs. J. Agric. Food Chem. 58, 7323-7328. doi: 10.1021/jf100927u

Lee, M. S., Huang, T. F., Toro-Ramos, T., Fraga, M., Last, R. L., and Jander, G. (2008). Reduced activity of Arabidopsis thaliana HMT2, a methionine biosynthetic enzyme, increases seed methionine content. Plant J. 54, 310-320. doi: 10.1111/j.1365-313X.2008.03419.x

Li, Z., Meyer, S., Essig, J. S., Liu, Y., Schapaugh, M. A., Muthukrishnan, S., et al. (2005). High-level expression of maize gamma-zein protein in transgenic soybean (Glycine max). Mol. Breed. 16, 11-20. doi: 10.1007/s11032-004-7658-6

Liao, D., Pajak, A., Karcz, S. R., Chapman, B. P., Sharpe, A. G., Austin, R. S., et al. (2012). Transcripts of sulphur metabolic genes are co-ordinately regulated in developing seeds of common bean lacking phaseolin and major lectins. J. Exp. Bot. 63, 6283-6295. doi: 10.1093/jxb/ers280

Lioi, L., Sparvoli, F., Galasso, I., Lanave, C., and Bollini, R. (2003). Lectin-related resistance factors against bruchids evolved through a number of duplication events. Theor. Appl. Genet. 107, 814-822. doi: 10.1007/s00122-003-1343-8

Malavolta, E., Vitti, G. C., Rosolem, C. A., Fageria, N. K., and Guimarães, P. T. G. (1987). Sulfur responses of Brazilian crops. J. Plant Nutr. 10, 2153-2158. doi: $10.1080 / 01904168709363766$

Marsolais, F., Pajak, A., Yin, F., Taylor, M., Gabriel, M., Merino, D. M., et al. (2010). Proteomic analysis of common bean seed with storage protein deficiency reveals up-regulation of sulfur-rich proteins and starch and raffinose metabolic enzymes, and down-regulation of the secretory pathway. J. Proteomics 73, 1587-1600. doi: 10.1016/j.jprot.2010.03.013
Maruyama-Nakashita, A., Nakamura, Y., Watanabe-Takahashi, A., Inoue, E., Yamaya, T., and Takahashi, H. (2005). Identification of a novel cis-acting element conferring sulfur deficiency response in Arabidopsis roots. Plant J. 42, 305-314. doi: 10.1111/j.1365-313X.2005.02363.x

Molvig, L., Tabe, L. M., Eggum, B. O., Moore, A. E., Craig, S., Spencer, D., et al. (1997). Enhanced methionine levels and increased nutritive value of seeds of transgenic lupins (Lupinus angustifolius L.) expressing a sunflower seed albumin gene. Proc. Natl. Acad. Sci. U.S.A. 94, 8393-8398. doi: 10.1073/pnas.94.16.8393

Montoya, C. A., Lallès, J. P., Beebe, S., and Leterme, P. (2010). Phaseolin diversity as a possible strategy to improve the nutritional value of common beans (Phaseolus vulgaris). Food Res. Int. 43, 443-449. doi: 10.1016/j.foodres.2009.09.040

Morton, R. L., Ellery, A. J., and Higgins, T. J. (1998). Downstream elements from the pea albumin 1 gene confer sulfur responsiveness on a reporter gene. Mol. Gen. Genet. 259, 309-316. doi: 10.1007/s004380050817

Naito, S., Hirai, M. Y., Inaba-Higano, K., Nambara, E., Fujiwara, T., Hayashi, H., et al. (1995). Expression of soybean seed storage protein genes in transgenic plants and their response to sulfur nutritional conditions. J. Plant Physiol. 145, 614-619. doi: 10.1016/S0176-1617(11)81272-1

Nordlee, J. A., Taylor, S. L., Townsend, J. A., Thomas, L. A., and Bush, R. K. (1996). Identification of a Brazil-nut allergen in transgenic soybeans. N. Engl. J. Med. 334, 688-692. doi: 10.1056/NEJM199603143341103

Osborn, T. C., Hartweck, L. M., Harmsen, R. H., Vogelzang, R. D., Kmiecik, K. A., and Bliss, F. A. (2003). Registration of Phaseolus vulgaris genetic stocks with altered seed protein compositions. Crop Sci. 43, 1570-1571. doi: 10.2135/cropsci2003.1570

Pandurangan, S., Pajak, A., Molnar, S. J., Cober, E. R., Dhaubhadel, S., HernandezSebastia, C., etal. (2012). Relationship between asparagine metabolism and protein concentration in soybean seed. J. Exp. Bot. 63, 3173-3184. doi: 10.1093/jxb/ers039

Prescott, V. E., Campbell, P. M., Moore, A., Mattes, J., Rothenberg, M. E., Foster, P. S., et al. (2005). Transgenic expression of bean $\alpha$-amylase inhibitor in peas results in altered structure and immunogenicity. J. Agric. Food Chem. 53, 9023-9030. doi: $10.1021 /$ jf050594v

Randall, P. J., Thomson, J. A., and Schroeder, H. E. (1979). Cotyledonary storage proteins in Pisum sativum. IV. Effects of sulfur, phosphorus, potassium and magnesium deficiencies. Aust. J. Plant Physiol. 6, 11-24. doi: 10.1071/PP9790011

Rerie, W. G., Whitecross, M., and Higgins, T. J. (1991). Developmental and environmental regulation of pea legumin genes in transgenic tobacco. Mol. Gen. Genet. 225, 148-157. doi: 10.1007/BF00282653

Rolletschek, H., Hosein, F., Miranda, M., Heim, U., Götz, K. P., Schlereth, A., et al. (2005). Ectopic expression of an amino acid transporter (VfAAP1) in seeds of Vicia narbonensis and pea increases storage proteins. Plant Physiol. 137, 12361249. doi: 10.1104/pp.104.056523

Sánchez, E., Ruiz, J. M., and Romero, L. (2002). Proline metabolism in response to nitrogen toxicity in fruit of French Bean plants (Phaseolus vulgaris L. cv Strike). Sci. Hortic. 93, 225-233. doi: 10.1016/S0304-4238(01)00342-9

Schmutz, J., Mcclean, P. E., Mamidi, S., Wu, G. A., Cannon, S. B., Grimwood, J., et al. (2014). A reference genome for common bean and genome-wide analysis of dual domestications. Nat. Genet. 46, 707-713. doi: 10.1038/ng.3008

Smith, F. W., Ealing, P. M., Hawkesford, M. J., and Clarkson, D. T. (1995). Plant members of a family of sulfate transporters reveal functional subtypes. Proc. Natl. Acad. Sci. U.S.A. 92, 9373-9377. doi: 10.1073/pnas.92.20.9373

Song, S., Hou, W., Godo, I., Wu, C., Yu, Y., Matityahu, I., et al. (2013). Soybean seeds expressing feedback-insensitive cystathionine $\gamma$-synthase exhibit a higher content of methionine. J. Exp. Bot. 64, 1917-1926. doi: 10.1093/jxb/ert053

Streit, L. G., Beach, L. R., Register, J. C., Jung, R., and Fehr, W. R. (2001). Association of the Brazil nut protein gene and Kunitz trypsin inhibitor alleles with soybean protease inhibitor activity and agronomic traits. Crop Sci. 41, 1757-1760. doi: $10.2135 /$ cropsci2001.1757

Tabe, L. M., and Droux, M. (2002). Limits to sulfur accumulation in transgenic lupin seeds expressing a foreign sulfur-rich protein. Plant Physiol. 128, 1137-1148. doi: 10.1104/pp.010935

Takahashi, H., Kopriva, S., Giordano, M., Saito, K., and Hell, R. (2011). Sulfur assimilation in photosynthetic organisms: molecular functions and regulations of transporters and assimilatory enzymes. Annu. Rev. Plant Biol. 62, 157-184. doi: 10.1146/annurev-arplant-042110-103921

Tan, Q., Zhang, L., Grant, J., Cooper, P., and Tegeder, M. (2010). Increased phloem transport of S-methylmethionine positively affects sulfur and nitrogen 
metabolism and seed development in pea plants. Plant Physiol. 154, 1886-1896. doi: 10.1104/pp.110.166389

Taylor, M., Chapman, R., Beyaert, R., Hernández-Sebastià, C., and Marsolais, F. (2008). Seed storage protein deficiency improves sulfur amino acid content in common bean (Phaseolus vulgaris L.): redirection of sulfur from $\gamma$-glutamyl-Smethyl-cysteine. J. Agric. Food Chem. 56, 5647-5654. doi: 10.1021/jf800787y

Townsend, J. A., and Thomas, L. A. (1994). Factors which influence the Agrobacterium-mediated transformation of soybean. J. Cell Biochem. (Suppl. 18A), 78.

Ufaz, S., and Galili, G. (2008). Improving the content of essential amino acids in crop plants: goals and opportunities. Plant Physiol. 147, 954-961. doi: 10.1104/pp.108.118091

Vigeolas, H., Chinoy, C., Zuther, E., Blessington, B., Geigenberger, P., and Domoney, C. (2008). Combined metabolomic and genetic approaches reveal a link between the polyamine pathway and albumin 2 in developing pea seeds. Plant Physiol. 146, 74-82. doi: 10.1104/pp.107.111369

Wu, Y., and Messing, J. (2014). Proteome balancing of the maize seed for higher nutritional value. Front. Plant Sci. 5:240. doi: 10.3389/fpls.2014.00240

Yenofsky, R. L., Fine, M., and Liu, C. (1988). Isolation and characterization of a soybean (Glycine max) lipoxygenase-3 gene. Mol. Gen. Genet. 211, 215-222. doi: 10.1007/BF00330597

Yin, F., Pajak, A., Chapman, R., Sharpe, A., Huang, S., and Marsolais, F. (2011). Analysis of common bean expressed sequence tags identifies sulfur metabolic pathways active in seed and sulfur-rich proteins highly expressed in the absence of phaseolin and major lectins. BMC Genomics 12:268. doi: 10.1186/1471-216412-268

Zhang, Y., Schernthaner, J., Labbé, N., Hefford, M. A., Zhao, J., and Simmonds, D. H. (2014). Improved protein quality in transgenic soybean expressing a de novo synthetic protein, MB-16. Transgenic Res. 3, 1-13. doi: 10.1007/s11248013-9777-5

Zuber, H., Davidian, J. C., Aubert, G., Aimé, D., Belghazi, M., Lugan, R., et al. (2010). The seed composition of Arabidopsis mutants for the group 3 sulfate transporters indicates a role in sulfate translocation within developing seeds. Plant Physiol. 154, 913-926. doi: 10.1104/pp.110.162123

Zuber, H., Poignavent, G., Le Signor, C., Aime, D., Vieren, E., Tadla, C., et al. (2013). Legume adaptation to sulfur deficiency revealed by comparing nutrient allocation and seed traits in Medicago truncatula. Plant J. 76, 982-996. doi: 10.1111/tpj.12350

Conflict of Interest Statement: The authors declare that the research was conducted in the absence of any commercial or financial relationships that could be construed as a potential conflict of interest.

Received: 14 November 2014; accepted: 04 February 2015; published online: 20 February 2015.

Citation: Pandurangan S, Sandercock M, Beyaert R, Conn KL, Hou A and Marsolais F (2015) Differential response to sulfur nutrition of two common bean genotypes differing in storage protein composition. Front. Plant Sci. 6:92. doi: 10.3389/fpls.2015.00092

This article was submitted to Plant Physiology, a section of the journal Frontiers in Plant Science.

Copyright (C) 2015 Pandurangan, Sandercock, Beyaert, Conn, Hou and Marsolais. This is an open-access article distributed under the terms of the Creative Commons Attribution License (CC BY). The use, distribution or reproduction in other forums is permitted, provided the original author(s) or licensor are credited and that the original publication in this journal is cited, in accordance with accepted academic practice. No use, distribution or reproduction is permitted which does not comply with these terms. 